\title{
PENGARUH GADGET PADA INTERAKSI SOSIAL DALAM KELUARGA
}

\author{
Oleh: \\ Inda Lestari, Agus Wahyudi Riana, \& Budi M.Taftarzani
}

Email:

(indalessembiring@yahoo.com; wahyudiriana@yahoo.com; budimtunpad@gmail.com)

\begin{abstract}
ABSTRAK
Dunia sudah memasuki era baru yaitu era teknologi dan komunikasi. Perkembangan teknologi dan komunikasi ini terjadi sangat pesat, teknologi terus menciptakan berbagai macam jenis gadget yang memiliki klasifikasi sebagai gadget high technology. Pada umumnya teknologi (gadget) telah menjadi bagian yang tidak dapat dipisahkan dari kehidupan seseorang, diperlukan upaya-upaya untuk meningkatkan kesadaran, pengetahuan, dan keterampilan agar tetap menggunakan internet lewat gadgetnya dengan cerdas. Namun dewasa ini gadget dalam penggunaannya sering kali terjadi secara berlebihan dan mempengaruhi berbagai aspek kehidupan. Pengaruh tersebut dapat dirasakan baik pada diri tersebut dan pada orang yang berada disekitar penggunanya. Salah satu lingkungan terdekat yang dikenai pengaruh oleh pengggunaan gadget pada adalah keluarga. Keluarga yang secara harfiah memiliki fungsi dan tanggung jawab masing-masing pada anggota keluarganya menjadi terganggu akibat adanya penggunaan gadget yang berlebihan pada penggunanya. Salah satu aspek yang terganggu dalam keluarga adalah aspek interaksi sosial antar anggota keluarga, yang mencakup di dalamnya pola komunikasi dan kontak sosial. Lewat komunikasi dan kontak sosial inilah perubahan interaksi sosial dalam keluarga tersebut dapat diukur. Adanya perbedaan dan perubahan komunikasi dan kontak sosial yang terjadi di dalam keluarga sebelum dan sesudah penggunaan gadget pada anggota keluarga dapat mempengaruhi pola interaksi sosial dalam keluarga secara menyeluruh. Dengan demikian dapat dilihat pengaruh atas penggunaan gadget tersebut terhadap interaksi sosial dalam keluarga.
\end{abstract}

Kata kunci : gadget, interaksi sosial, keluarga.

\section{PENDAHULUAN}

Dunia sudah memasuki era baru yaitu era teknologi dan komunikasi. Perkembangan teknologi terjadi sangat pesat, teknologi terus menciptakan berbagai macam jenis gadget yang memiliki klasifikasi sebagai gadget high technology. Ada banyak varian gadget yang kini tersebar di Indonesia khususnya seperti smartphone, tablet, komputer, kamera, laptop dan lainnya. Penggunaan bermacam jenis gadget kini telah menjadi gaya hidup di Indonesia. Penggunaan gadget dapat dilihat langsung di tempat-tempat umum seperti sekolah, stasiun, terminal, halte bahkan di bus sekalipun. Pengguna alat sosial media ini seakan telah membudaya di masyarakat Indonesia.

Penggunaan gadget telah mencapai pasar umum, dalam artian kalangan dan dimensi umur tidak lagi menjadi penghalang dalam penggunaan gadget. Berikut gambar dari grafik penggunaan handphone di Indonesia yang dilakukan oleh tecno journal. 


\section{Mobile Consumers are getting younger $\rightarrow 15-19$ yo and more recently $10-14$ yo driving the growth}

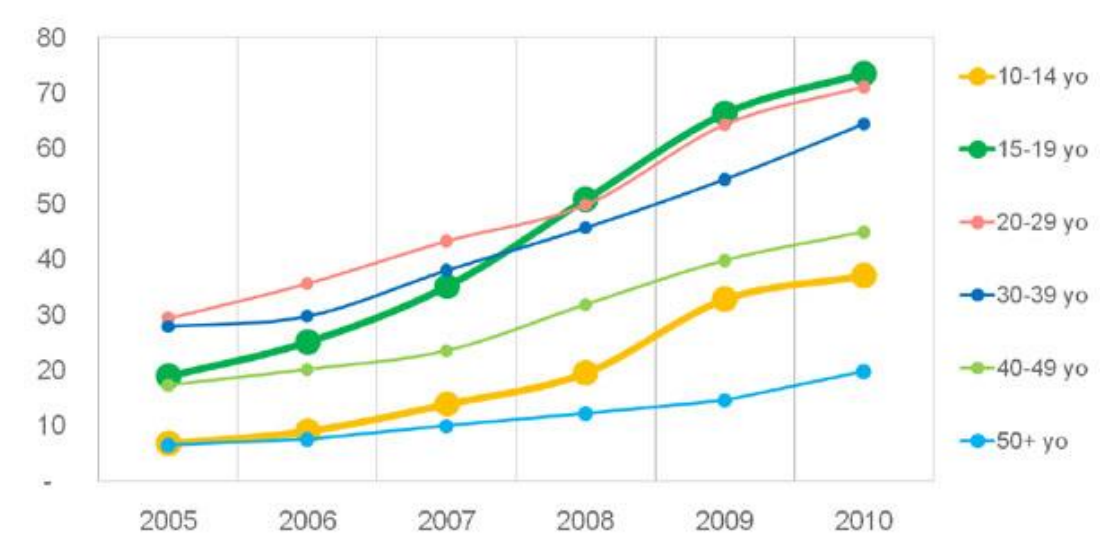

Gambar 1.1 Konsumen handphone di Indonesia berdasarkan umur

Dapat dilihat dari gambar tersebut pengguna handphone di Indonesia pada tahun 2005-2010 telah menyentuh rentan umur mulai dari 10 hingga 50 tahun atau lebih. Hal tersebut memperlihatkan bahwa penggunaan gadget (handphone) tidak memberikan batasan umur bagi penggunanya.

Kini pengguna gadget menghabiskan banyak waktunya untuk sekedar bermain dengan gadget mereka tanpa kepentingan yang penting atau mendesak. Gadget digunakan untuk berbagai macam keperluan. Pada umumnya gadget digunakan untuk melakukan komunikasi jarak jauh yang dalam kata lain komunikasi tersebut dapat dilakukan tanpa bertemu secara langsung. Namun seiring berkembangnya teknologi, fitur yang terdapat pada gadget semakin berkembang dan beragam. Kini gadget selain berfungsi untuk mempermudah manusia melakukan komunikasi antar pribadi, gadget juga dapat menjadi media aktualisasi diri yaitu dengan penggunaan fitur social media seperti facebook, twitter, instagram, dan path. Selain itu gadget juga digunakan sebagai alat hiburan, gadget kini memliki fitur games atau fitur hiburan dan informasi lainnya seperti youtube sebagai penghilang jenuh di waktu senggang.

Namun yang terjadi adalah penggunaan gadget ini mulai sulit terkontrol, mulai dari waktu penggunaan hingga tempat penggunaan. Pengguna gadget ini menggunakan gadget-nya kapanpun dan dimanapun. Fenomena komunikasi yang dipengaruhi pula oleh media yang digunakan, sehingga media kadang kala juga ikut memengaruhi isi informasi (I) dan penafsiran (II), bahkan menurut Marshall McLuhan dalam Bungin (2006:57) media juga adalah pesan itu sendiri. Sehingga penggunaan gadget tersebut mengganggu komunikasi sehari-hari termasuk di dalam aktivitas interaksi di dalam keluarga.

Pada awalnya gadget yang berfungsi memudahkan upaya interaksi antar individu kini mulai berdampak sebaliknya. Pengguna gadget kini lebih sering menghabiskan waktunya dengan gadgetnya daripada bercengkrama atau sekedar menghabiskan waktu mengobrol bersama dengan anggota keluarga yang lain. Penggunaan gadget yang tidak terkontrol seperti inilah yang dapat mengganggu proses interaksi sosial. Atau bahkan bisa jadi terisolasi dari lingkungan sosialnya, termasuk di dalam lingkungan sosial terdekatnya yaitu keluarga. Interaksi sosial dengan segala aspek yang berhubungan dengan interaksi tersebut seperti bagaimana interaksi (komunikasi) itu dilakukan dengan menggunakan media, bagaimana efek media sebagai akibat dari interaksi tersebut, sampai dengan bagaimana perubahan-perubahan sosial di masyarkat yang didorong oleh efek media berkemvang serta konsekuensi sosial macam apa yang ditanggung masyarakat sebagai akibat dari perubahaan yang didorong oleh media itu sendiri (Bungin, 2006:57). Bila pengguna gadget ini terus dibiarkan tanpa diberikan pemahaman atas dampak lain selain diluar gadget secara fungsional banyak memberikan kemudahan bagi penggunanya bisa jadi para pengguna gadget mulai sulit berinteraksi 
secara nyata dengan keluarganya. Dan hal tersebut dapat mempengaruhi keseluruhan dari keluarganya.

Penggunaan gadget dalam keluarga mempengaruhi keseluruhan interaksi sosial dalam keluarga tersebut. Dimana interaksi yang biasanya dilakukan antara orang tua pada anaknya sebagai bentuk pengasuhan dan komunikasi untuk menciptakan kekukuhan keluarga akan terganggu, hal tersebut dikarenakan keluarga merupakan kesatuan sistem yang utuh, dimana bila salah satu anggota keluarga mengalami kesulitan dalam melakukan interaksi secara langsung, hal tersebut membuat keluarga secara sadar atau tidak akan mengurangi atau melakukan perubahan dalam pola interaksi sosialnya.

Interaksi yang pada awalnya dilakukan secara langsung (tatap muka) kini mulai digantikan menjadi interaksi dengan gadget. Perubahan dalam pola interaksi sosial dalam keluarga tersebut menghasilkan pola sikap yang menjadi lebih individualis. Sebab perubahan interaksi langsung menjadi interaksi yang lebih sering dilakukan dengan gadget memiliki perbedaan. Diantara peran emosional dan kontak sosial yang tidak dilakukan secara utuh.

Bentuk interaksi sosial dalam keluarga yang dipengaruhi oleh penggunaan gadget dapat mengubah fungsi dari keluarga itu sendiri. Dimana perilaku antar orangtua, atat orangtua kepada anak dalam pengasuhannya tidak terjalin secara utuh, dimana komunikasi, kedekatan, dukungan maupun keterlibatan orangtua tidak lagi dirasakan atau dilakukan dengan maksimal. Seperti definisi keluarga dari sudut pandang fungsional menurut Konner dan Mary Anne Fitzpatrick (2004) yaitu definisi keluarga yang mencakup pada terpenuhinya tugas-tugas dan fungsi-fungsi psikososial. Fungsi-fungsi tersebut mencakup perawatan, sosialisasi pada anak, dukungan emosi dan materi, dan pemenuhan peran-peran tertentu. Definisi ini memfokuskan pada tugas-tugas yang dilakukan oleh keluarga.

\section{PEMBAHASAN \\ Interaksi Sosial dalam Keluarga}

Keluarga adalah sekelompok orang yang diikat oleh perkawinan atau darah, biasanya meliputi ayah, ibu, dan anak atau anak-anak. Keluarga juga merupakan kelompok sosial yang pertama dalam kehidupan manusia, tempat ia belajar dan menyatakan diri sebagai manusia sosial dalam hubungan interaksi dengan kelompoknya (W.A Gerungan,200:194) . Di dalam keluarga pertama kalinya interaksi kelompok berlaku. Keluarga menjadi kelompok primer yang termasuk pembentukannya norma-norma sosial, internalisasi norma-norma, terbentuknya frame of reference, behaviorisme, dan lain-lain.

Keluarga dalam lingkungan sosial masyarakat memiliki status sebagai bagian dari kesatuan masyarakat dan sebagai penghubung pribadi dengan struktur yang lebih luas (masyarakat). Dalam masyarakat, keluarga berperan sebagai pelestari suatu masyarakat, pemelihara fisik anggotanya dalam pembentukan kelestarian masyarakat, wadah sosialisasi anak sebagai sarana kontrol sosial.

Pemahaman atas keluarga sebagai unit sosial terkecil dan menjadi sosialisasi terdekat inilah yang mendasari kebutuhan sistem keluarga dalam melakukan interaksi sosial untuk mrndapatkan hubungan yang dinamis. Pengertian interaksi sosial menurut Soerjono Soekanto dalam Burhan Bungin (2006:55) bahwa Interaksi sosial merupakan hubungan sosial yang dinamis menyangkut hubungan antara orang perorangan, antara kelompok-kelompok manusia, maupun antara orang perorangan dengan kelompok manusia. Yang juga dikuatkan oleh Seodjono Dirdjosisworo dalam Nasrullah Nazsir (2008:26) lewat upaya proses sosial yang dilakukan dalam anggota atau bagian dari interaksi tersebut dimana beliau mengatakan bahwa proses sosial yang menunjuk pada hubungan sosial yang dinamis.

\section{Kontak dan Komunikasi Sebagai Syarat Interaksi Sosial}

Proses interaksi sosial memiliki dua syarat utama yaitu kontak sosial (social contact) dan komunikasi (communication). Kontak sosial berasal dari bahasa latin con atau cum (bersama-sama) 
dan tango (menyentuh), jadi, artinya secara harfiah adalah bersama-sama menyentuh (Soekanto dalam Bungin, 2006:55). Artinya secara harfiah adalah bersama-sama menyentuh. Secara fisik, kontak sosial baru terjadia apabila adanya hubungan fisikal, sebagai gejala sosial hal itu bukan semata-mata hubungan badaniah, karena hubungan sosial terjadi tidak saja secara menyentuh seseorang, namun orang dapat berhubungan dengan orang lain tanpa harus menyentuhnya (Bungin, 2006:56). Namun Syani dalam Baswori (2005:141) mengatakan bahwa kontak sosial adalah hubungan antara satu orang atau lebih melalui percakapan dengan saling mengerti tentang maksud dan tujuan masing-masing dalam kehidupan masyarakat, konflik sosial pihak satu dengan pihak lainnya.

Suatu kontak juga dapat pula bersifat primer atau sekunder. Dimana kontak primer terjadi apabila mengadakan hubungan langsung bertemu dan berhadapan. Sedangkan kontak sekunder memerlukan suatu perantara untuk saling berhubungan yang bersifat manusiawi maupun dengan teknologi.

Ketika masyarakat saat ini telah berkembang dengan tingkat kemajuan teknologi yang sangat pesat dan canggih, maka kontka-kontak sosial primer dan sekunder ini semakin sulit dibedakan satu dengan lainnya. Seperti penggunaan gadget yang membantu proses kontak sosial terjadi dengan lebih mudah. Hal tersebut membuat konsep kontak sosial menjadi samar.

Syarat kedua dalam melakukan interaksi sosial adalah komunikasi. Menurut Soejono Soekanto (2006:60) arti terpenting komunikasi adalah bahwa seseorang memberikan tafsiran pada perilaku orang lain (yang berwujud pembicaraan, gerak-gerak badaniah atau sikap). Komunikasi dapat diartikan sebagai pandangan antara orang-orang yang berinteraksi terhadap sesuatu. Adanya komunikasi yaitu seseorang memberi arti pada perilaku orang lain, perasaan-perasaan apa yang ingin disampaikan oleh orang tersebut. Orang bersangkutan kemudian memberi reaksi terhadap perasaan yang ingin disampaikan oleh orang tersebut. Dalam komunikasi kemungkinan sekali terjadi berbagai macam penafsiran terhadap tingkah laku orang lain. Dengan demikian , komunikasi memungkinkan kerjasam antara orang perorangan atau antara kelompok-kelompok manusia.

Sosiologi menjelaskan komunikasi sebagai sebuah proses memaknai yang dilakukan oleh seseorang (I) terhadap informasi, sikap, dan perilaku orang (II) lain yang berbentuk pengetahuan, pembicaraan, gerak-gerik, atau sikap, perilaku dan perasaan-perasaan, sehingga seseorang (I) membuat reaksi-reaksi terhadap informasi, sikap, dan perilaku tersebut berdasarkan pada pengalaman yang pernah dia (I) alami. ), menurut Marshall McLuhan dalam Bungin (2006:57)Fenomena komunikasi yang dipengaruhi pula oleh media yang digunakan, sehingga media kadang kala juga ikut memmengaruhi isi informasi (I) dan penafsiran (II).

Dalam komunikasi ada tiga unsur penting yang selalu hadir dalam setiap komunikasi, yaitu sumber informasi (receiver), slauran (media), dan penerima informasi (audience). Sumber informasi adalah seseorang atau institusi yang memiliki bahan informasi (pemberitaan) untuk disebarkan kepada masyarkat luas. Saluran adalah media yang digunakan untuk kegiatan pemberitaan oleh sumber berita, berupa media interpersonal yang digunakan secara tatap muka maupun media massa yang digunakan untuk khalayak umum. Sedangkan audience adalah per orang atau kelompok dan masyarakat yang menjadi sasaram informasi atau yang menerima informasi.

\section{Bidang Praktek Pekerjaan Sosial dalam Interaksi Sosial}

Pekerjaan sosial merupakan pekerjaan yang many faces (mempunyai bentuk wajah) karena menangani berbagai macam permasalahan manusia dan melakukan berbagai kegiatan perubahan sosial. Dalam proses pertolongannya pekerjaan sosial merupakan sebuah profesi yang komprehensif artinya tidak memandang dari salah satu perspektif saja, melainkan lebih bersifat menyesuaiakan dengan setting lapangan yang ada (Dwi Heru Soekoco, 1995:59). Pekerjaan sosial merupakan profesi pertolongan yang bertujuan untuk meningkatkan individu, kelompok, dan masyarakat untuk mencapai tingkat kesejahteraan sosial, mental, dan psikis yang sebaik-baikmya. 
Definisi pekerjaan sosial menurut Allen Pincus dan Anne Minahan (dalam Dwi Heru Soekoco, 1995:59): "Social work is concerned with the interaction between people and their social environment which affect the ability of people to accomplish their life task, alleviate distress, and realize their aspiration and values". Definisi tersebut menunjukkan bahwa pekerjaan sosial berkepentingan dengan permasalahan interaksi antara orang dengan lingkungan sosialnya, sehingga mereka mampu melaksanakan tugas-tugas kehidupan, mengurangi ketegangan, mewujudkan aspirasi dan nilai-nilai mereka.

Dari pemeaparan diatas, pekerjaan sosial sangat berkaitan dengan interaksi antara orang dengan lingkunganya sosialnya. Oleh sebab itu, kegiatan pekerjaan sosial diarahkan kepada peningkatan kesejahteraan seseorang terkait interaksinya dengan lingkungan sosialnya. Dalam hal ini yaitu remaja dengan lingkungan sosialnya yaitu keluarga yang dipengaruhi oleh penggunaannya terhadap gadget.

Boehm seperti yang dikutip oleh Renny Sekarningsih dalam Soetarso (1992:19) mendefinisikan pekerjaan sosial sebagai profesi yang :

"... berusaha untuk menignkatkan kemampuan individu, baik secara perorangan maupun dalam satu kelompok, untuk melaksanakan fungsi sosial melalui berbagai kegiatan yang dipusatkan pada antar hubungan sosial mereka yang merupakan interaksi antara orang dengan lingkungannya. Kegiatan-kegiatan tersebut dapat dikelompokkan ke dalam tiga fungsi, yaitu pemulihan kemampuan orang, pengadaan sumber-sumber manusia dan sosial, serta pencegahan terhadap disfungsi sosial."

Adapun fungsi pekerjaan sosial sebagaimana diungkapkan Soetarso (1992:6) yaitu :

1. Membantu orang meningkatkan dan menggunakan secara lebih efektif kemampuan untuk melaksanakan tugas dan memecahkan masalahnya.

2. Menciptakan jalur hubungan pendahuluan diantara orang dengan sistem sumber.

3. Mempermudah interaksi, menambah dan menciptakan hubungan baru antara orang dengan sistem sumber kemasyarakatan.

4. Memberikan sumbangan bagi perubahan, perbaikan, dan perkembangan kebijakan atau perundang-undangan sosial.

5. Masyarakat sumber sosial.

6. Bertindak sesuai pelaksanaan kontrol sosial.

\section{PENUTUP}

Penggunaan gadget pada era teknologi seperti sekarang dapat mempengaruhi aspek kehidupan lainnya. Dimana Aseperti yang dikatakan oleh McLuhan bahwa media dapat mengubah pola komunikasi seserorang. Gadget sebagai media secara umum memiliki fungsi positif pagi penggunanya. Namun penggunaan gadget yang kurang cerdas baik secara kuantiitas atau kualitas dapat memberikan dampak yang lain, termasuk pada keluarga sebagai lingkungan sosial terdekat bagi suatu individu.

Keluarga sebagai kelompok primer bagi suatu individu memiliki peran dalam hal sosial. Penggunaan gagdet yang tidak cerdas pada anggota keluarga berpotensi untuk mengubah peran-peran dari keluarga tersebut dan mempengaruhi fungsi keluarga secara keseluruhan bagi setiap anggota keluarga.

Fenomena penggunaan gadget pada anggota keluarga yang pada akhirnya berpotensi mengubah suatu pola interaksi sosial di dalam keluarga ini dapat diminimaisir dengan pemberian intervensi dari pekerja sosial keluarga sesuai fungsinya. Pekerja sosial keluarga dapat berupaya melakukan family therapy yang disesuaikan dengan kebutuhan keluarga guna menyadarkan akan perubahan pola interaksi yang berpotensi mempengaruhi peran dam fungsi keluarga secara 
keseluruhan. Sehingga keluarga dapat memperbaiki pola penggunaan gagdet minimal dalam keadaan berinteraksi dengan keluarga.

Intensitas penggunaan gadget memiliki hubungan yang dapat mempengaruhi pola interaksi sosial didalam keluarga. Dimana hakikatnya gadget dibuat dengan fungsi untuk mempermudah kegiatan seseorang, dalam artian fungsi gadget disini adalah baik. Namun dapat mengalami perubahan fungsi bila penggunaan gadget tersebut tidak dibarengi dengan ilmu yang cukup, dalam artian harus adanya pengelolaan dan pengendalian penggunaan gadget mulai dari kuantitas waktu pengguna sampai pada kualitas isi dari pengguna yang dilakukan.

\section{Sumber Buku}

\section{DAFTAR RUJUKAN}

Bungin, Burhan. 2006. Sosiologi Komunikasi: Teori, Paradigma, dan Diskursus

Teknologi Komunikasi di Masyarakat (Edisi Pertama). Jakarta: Kencana Prenada Media Group.

Gerungan, W.A. 2009. Psikologi Sosial (Edisi Ketiga). Bandung: PT. Refika Aditama

Goode, William J. 2002. Sosiologi Keluarga. Terjemahan Lailahanoum Hasyim. Jakarta: Bumi Aksara Jakarta.

Mulyana, Deddy. 2010. Ilmu Komunikasi Suatu Pengantar. Bandung: PT. Remaja Rosdakarya.

Nazsir, Nasrullah. 2008. Sosiologi. Bandung: Widya Padjadjaran

Skidmore, R.A., M.G. 1994. Introduction in Social Work Sixth Edition. University of Utah

Soekanto, Soeryono. 2007. Sosiologi suatu pengantar. Jakarta: PT. RajaGrafindo Persada

Soelaeman, M. Munandar. 2006. Ilmu Sosial Dasar: Teori \& Konsep Ilmu Sosial (Edisi Kelima). Bandung: PT. Refika Aditama

Sunarto, Kamanto. 2004. Pengantar Sosiologi (Edisi Ketiga). Jakarta: Lembaga Penerbit Fakultas Ekonomi Universitas Padjadjaran

Walgito, Bimo 1978. Psikologi Sosial (Suatu Pengantar). Yogjakarta: Andi Offset

Wibhawa, Budhi dkk. 2010. Dasar-Dasar Pekerjaan Sosial. Bandung: Widya Padjadjaran.

Willis, Sofyan S. 2011. Konseling Keluarga (Family Counseling). Bandung: Alfabeta

\section{Sumber Lain}

Ayu, Sukma DW. (2013). Dinamika Komunikasi Keluarga Pengguna Gadget (skripsi). Jurusan Psikologi. Fakultas Ilmu Sosial dan Humaniora. Universitas Islam Negeri Sunan Kalijaga. Yogjakarta

http://teknojurnal.com/perkembangan-pasar-handphone-di-Indonesia-dari-tahun- 2005-hingga2010/ diakses pada tanggal 25 April 2014 pukul 20.30 WIB

http://www.sumbaronline.com/berita-15577-teknologi-dan-interaksi-sosial.html diakses 25 April 2014, 20.00

http://www.anneahira.com/komunikasi-dalam-keluarga.html, diakses pada tanggal 27 April 2014 pukul 20.00 WIB

http://www.nuga.co/nuga-life/gadget-kini-sudah-jadi-wabah-pengganggu.html, diakses pada tanggal 27 Agustus 2014 pokul $20.00 \mathrm{WIB}$ 